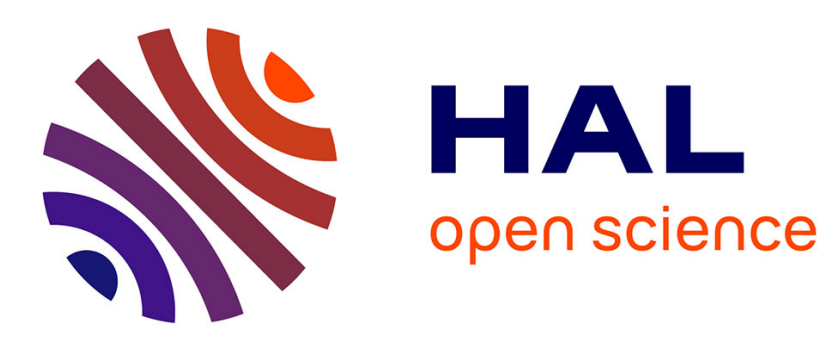

\title{
Chemical Deposition of Zinc Hydroxosulfide thin Films from Zinc (II) - Ammonia-Thiourea Solutions
}

\author{
B. Mokili, M. Froment, D. Lincot
}

\section{To cite this version:}

B. Mokili, M. Froment, D. Lincot. Chemical Deposition of Zinc Hydroxosulfide thin Films from Zinc (II) - Ammonia-Thiourea Solutions. J. Phys. IV, 1995, 05 (C3), pp.C3-261-C3-266. 10.1051/jp4:1995324 . jpa-00253690

\section{HAL Id: jpa-00253690 https://hal.science/jpa-00253690}

Submitted on 1 Jan 1995

HAL is a multi-disciplinary open access archive for the deposit and dissemination of scientific research documents, whether they are published or not. The documents may come from teaching and research institutions in France or abroad, or from public or private research centers.
L'archive ouverte pluridisciplinaire HAL, est destinée au dépôt et à la diffusion de documents scientifiques de niveau recherche, publiés ou non, émanant des établissements d'enseignement et de recherche français ou étrangers, des laboratoires publics ou privés. 


\title{
Chemical Deposition of Zinc Hydroxosulfide thin Films from Zinc (II) - Ammonia-Thiourea Solutions
}

\author{
B. Mokili, M. Froment* and D. Lincot(1) \\ Laboratoire d'Electrochimie et de Chimie Analytique, Unité Associée au CNRS, Ecole Nationale Supérieure \\ de Chimie de Paris, 11 rue Pierre et Marie Curie, 75231 Paris cedex 05, France \\ * UPR 15 du CNRS "Physique des Liquides et Electrochimie", Université Pierre et Marie Curie, \\ 75252 Paris cedex 05, France
}

\begin{abstract}
The growth of $\mathrm{ZnS}$ films from ammonia solutions using thiourea as a sulfur precursor has been investigated. In situ growth kinetic studies have been performed by means of the quartz crystal microbalance (QCM) technique. The experiments have been carried out in $\mathrm{pH}$ buffered conditions $(\mathrm{pH} \approx 11)$ and the effect of the addition of amines has been investigated. The film are characterized by various techniques (Optical, Rutherford Back Scattering, Transmission Electron Microscopy). The composition of zinc hydroxosulfide is ranging between almost pure $\mathrm{ZnS}$ to mainly $\mathrm{Zn}(\mathrm{OH})_{2}$ depending on the deposition conditions.
\end{abstract}

\section{INTRODUCTION}

Zinc sulfide is a large gap semiconductor $(\mathrm{Eg}=3.6 \mathrm{eV})$ which is widely used in thin film devices, such as photoluminescent and electroluminescent devices and which can be used as a window layer for thin film heterojonction solar cells [1-2].

Zinc sulfide has been prepared by a variety of methods, including evaporation metal-organic chemical vapor deposition, molecular beam epitaxy and atomic layer epitaxy. The deposition of thin films of ZnS can be obtained by direct reaction between precusor species in solution at low temperatures $\left(<100^{\circ} \mathrm{C}\right)$. This process, called chemical bath deposition (CBD) uses the reaction between thiourea $[2,3]$ or thioacetamide $[1,4-6]$ and dissolved zinc ions in solution. It is analogue to chemical deposition in the vapor phase (CVD).

We report here some studies on the deposition of zinc sulfide thin films from $\mathrm{NH}_{3} / \mathrm{NH}_{4} \mathrm{Cl}$ solutions, in the presence of thiourea and zinc chloride as precursors. As compared to [2], the addition of ammonium ions allow to fix the $\mathrm{pH}$ of the solution in a less basic range and to stabilize the growth conditions. Moreover recent studies for $\mathrm{CdS}$ tend to show that the quality of CdS layers is better in $\mathrm{pH}$ buffered conditions [7].

One problem arizing with $\mathrm{ZnS}$ as compared to $\mathrm{CdS}$ is the much lower deposition rate in presence of thiourea. To avoid this problem it has been shown recently that the addition of hydrazine increased markedly the growth rate in basic solution (unbuffered)[2]. In this paper, the influence of hydrazine and other amines has been studied.

In situ studies have been carried out by means of the quartz crystal microbalance technique (QCM) $[1,8]$.

\section{SOLUTION CHEMISTRY ANALYSIS}

The mechanism of sulfide films by CBD is generally represented by the following steps[9] :

$$
\begin{gathered}
\mathrm{Zn}(\mathrm{L})_{\mathrm{n}} \rightarrow \mathrm{Zn}^{2+}+\mathrm{nL} \quad \text { (1) } \\
\mathrm{SC}\left(\mathrm{NH}_{2}\right)_{2}+2 \mathrm{OH}^{-} \rightarrow \mathrm{S}^{2-}+\mathrm{H}_{2} \mathrm{CN}_{2}+2 \mathrm{H}_{2} \mathrm{O} \\
\mathrm{Zn}^{2+}+\mathrm{S}^{2-} \rightarrow \mathrm{ZnS}
\end{gathered}
$$

(1) Author of correspondence 
where $\mathrm{L}$ is a ligand, as $\mathrm{NH}_{3}$ for $\mathrm{Zn}^{2+}$. Step one corresponds to the decomplexation reaction, step two to the hydrolysis of thiourea (which may be considered as reversible $[10,11]$ ) leading to the formation of sulfide ions which react with free cations to form $\mathrm{ZnS}$.

Recently another mechanism has been proposed for CdS [8], which involves chemical steps at the surface. If we admit that the mechanism of the deposition of $\mathrm{ZnS}$ is similar to that proposed for CdS, we can write:

$$
\begin{gathered}
\mathrm{Zn}(\mathrm{L})_{\mathrm{n}}^{2+}+\mathrm{site}+2 \mathrm{OH}^{-} \Leftrightarrow \mathrm{Zn}(\mathrm{OH})_{2} \text {, ads }+\mathrm{nL} \quad \text { (i) } \\
\mathrm{SC}\left(\mathrm{NH}_{2}\right)_{2}+\mathrm{Zn}(\mathrm{OH})_{2} \text {, ads } \rightarrow \mathrm{ZnS}+2 \mathrm{H}_{2} \mathrm{O}+\mathrm{CN}_{2} \mathrm{H}_{2}+\text { site }
\end{gathered}
$$

In this mechanism the adsorption of zinc hydroxide plays a key role and catalyses the decomposition of thiourea at the surface. The role of the metal hydroxide in the reaction process was recognized also from earlier studies $[12,13]$. If we consider the solubility products of $\mathrm{Zn}(\mathrm{OH})_{2}, \mathrm{~K}_{\mathrm{s}}=10^{-15.3}$ and $\mathrm{ZnS}$, $\mathrm{K}_{\mathrm{s}} \approx 10^{-23.8}$ [14], it appears that a competition between the formation of both compounds is possible in basic solutions. To obtain $\mathrm{ZnS}$ the formation of $\mathrm{Zn}(\mathrm{OH})_{2}$ must be minimized, i.e. the ionic product must remain below the solubility product.

From an analysis of the solution chemistry the repartition of the soluble species and the solubility limit of $\mathrm{Zn}(\mathrm{OH})_{2}$ can be calculated in various conditions. Using the values of the stability constants reported in table $\mathrm{I}$, the solubility diagram corresponding to the selected range of $\mathrm{pH}$ has been established (figure 1).

\begin{tabular}{|c|c|c|c|c|}
\hline \multicolumn{5}{|c|}{$\log \beta_{\mathrm{L}, \mathrm{n}}$} \\
\cline { 2 - 5 } $\mathrm{n}$ & 1 & 2 & 3 & 4 \\
\hline $\mathrm{OH}^{-}$ & 4.4 & & 14.4 & 15.5 \\
\hline $\mathrm{SC}\left(\mathrm{NH}_{2}\right)_{1}$ & 0.5 & 0.8 & 0.9 & \\
\hline $\mathrm{NH}_{3}$ & 2.27 & 4.61 & 7.01 & 9.06 \\
\hline $\mathrm{HZ}$ & 3.4 & 3.7 & 3.8 & 3.9 \\
\hline $\mathrm{EA}$ & 3.7 & 6.1 & 9.4 & \\
\hline $\mathrm{TEA}$ & 2.0 & & & \\
\hline
\end{tabular}

Table I: Values of the stability constants used in the model $[14,16,17]$.

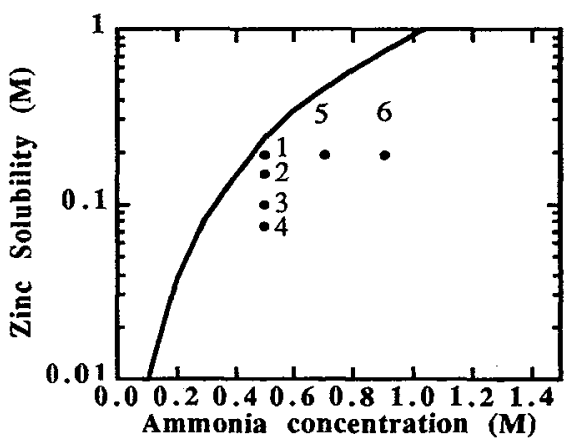

Figure 1: Solubility diagram of $\mathrm{Zn}(\mathrm{OH})_{2}$ as function of free ammonia concentration at $\left[\mathrm{NH}_{4}^{+}\right]=0.02 \mathrm{M} ;$ Solid circles 1 to 4 $\left[\mathrm{ZnCl}_{2}\right]=0.19,0.15,0.10,0.075 \mathrm{M}$ at $\left[\mathrm{NH}_{3}\right]_{\text {free }}=0.5 \mathrm{M} ;$ Solid circles 1,5 and 6 $\left[\mathrm{NH}_{3}\right]_{\text {free }}=0.9,0.7,0.5 \mathrm{M}$ at $\left[\mathrm{ZnCl}_{2}\right]=0.19 \mathrm{M}$.

For $\mathrm{ZnS}$, the estimation of the precipitation line can be made by assuming that the decomposition of thiourea is reversible.

$$
\mathrm{SC}\left(\mathrm{NH}_{2}\right)_{2}+2 \mathrm{OH}^{-} \Leftrightarrow \mathrm{S}^{2-}+\mathrm{H}_{2} \mathrm{CN}_{2}+2 \mathrm{H}_{2} \mathrm{O}
$$

with $\mathrm{K}=2.2510^{-15}[7]$ considering also that cyanamide and sulfide had acid functions $\left(\mathrm{pK}_{\mathrm{a}}=11.82\right.$ $\mathrm{pK}_{\mathrm{a} 2}=10.28$ for cyanamide) [12], and the also for sulfide.

\section{EXPERIMENTAL}

The substrates were glass slides, $\mathrm{SnO}_{2}$ on glass or $\mathrm{Si}(111)$ or $\mathrm{Si}(100)$ slides. Glass and $\mathrm{SnO}_{2}$ slides were degreased with a detergent solution, cleaned in concentrated sulphuric acid. Si slides were degreased with ethanol, etched in $\mathrm{HF} / \mathrm{NH}_{4} \mathrm{Cl}$ solution to remove the oxide. All were then rinsed in milli-QH water. 
The slides were mounted vertically in a glass beaker containing the deposition solution at a temperature of $85^{\circ} \mathrm{C}$.

Stock solutions of $\mathrm{ZnCl}_{2}, \mathrm{ZnSO}_{4}, \mathrm{NH}_{3}, \mathrm{NH}_{4} \mathrm{Cl}$, Thiourea (Tu), Ethanolamine (EA), Triethanolamine (TEA) and Hydrazine (HZ) of different concentrations have been prepared from reagent grade chemicals.

Zinc salt is mixed with ammonia solution under vigorous stirring until the dissolution is completed. This solution is introduced into the reaction vessel and heated to the desired temperature in the presence of the quartz microbalance. The thiourea is added from a few $\mathrm{ml}$ of sotck solution. The solution $\left(50 \mathrm{~cm}^{3}\right)$ was stirred magnetically during the deposition.

The quartz crystal microbalance (MAXTEK Inc. Model PM 500) works at a frequency of $6 \mathrm{MHz}$. It consisted of a polished gold electrode $\left(1.4 \mathrm{~cm}^{2}\right)$. The equivalent thickness is obtained directely from the set up by introducing the density of $\mathrm{ZnS}: 4.09 \mathrm{~g} \mathrm{~cm}^{-3}$, and the acoustic impedance factor: $11.3910^{5} \mathrm{~g} \mathrm{~cm}^{-2} \mathrm{~s}^{-1}$.

\section{RESULTS AND DISCUSSION}

\subsection{In situ kinetic study}

The conditions of deposition are indicated in figure 1. They correspond to conditions below the precipitation line of both the hydroxide and the sulfide, except conditions (1) which are close to the precipitation. At room temperature all these solution remain clear, with no evidence for precipitation, in agreement with the solubility diagrams.

In figure 2,3 and 4 are reported the influence of the total zinc, the free $\mathrm{NH}_{3}$ and thiourea concentrations respectively, while the other parameters were kept constant. The corresponding points are reported in the solubility diagram (figure 1). Considering an individual curve, it appears that the growth starts almost immediatly, without marked induction times, and proceeds more or less linearly as a function of time. This behavior is different from that observed with $\mathrm{CdS}$ [8] but similar to that reported in previous studies for $\mathrm{ZnS}[1]$. It also appears that the growth rates are rather low $(<0.1 \mu \mathrm{m} / \mathrm{h})$. This was also reported at higher $\mathrm{pH}[2]$.

As expected from the mechanism, increasing the precursor concentrations, zinc chloride (figure 2) and thiourea (figure 3) increases the growth rates, however the effect is more pronounced with zinc than with thiourea. Increasing the free ammonia concentration leads to a decrease of the rate, due to a displacement of equilibria (1) and (i) to the left.

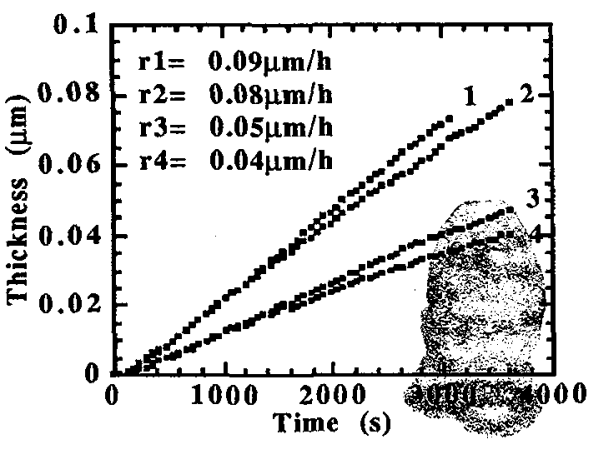

Figure 2: Thickness evolution with deposition time for samples prepared at different concentrations of zinc. Conditions:

$[\mathrm{Tu}]=0.1 \mathrm{M},\left[\mathrm{NH}_{4} \mathrm{Cl}\right]=0.02 \mathrm{M}, \mathrm{T}=85^{\circ} \mathrm{C}$;

1 to $4\left[\mathrm{ZnCl}_{2}\right]=0.19,0.15,0.10,0.075 \mathrm{M}$ and $\left[\mathrm{NH}_{3}\right]=1.26,1.1,0.9,0.8 \mathrm{M}$.

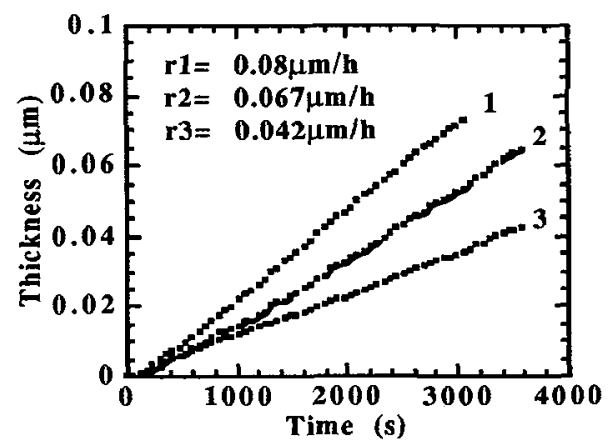

Figure 3: Thickness evolution with deposition time for sample prepared at different concentrations of ammonia. Conditions:

$[T u]=0.1 \mathrm{M},\left[\mathrm{ZnCl}_{2}\right]=0.19 \mathrm{M}$, $\left[\mathrm{NH}_{4} \mathrm{Cl}\right]=0.02 \mathrm{M}, \mathrm{T}=85^{\circ} \mathrm{C}, 1$ to 3 $\left[\mathrm{NH}_{3}\right]=1.66,1.46,1.26 \mathrm{M}$.

Contrary to the case of CdS [8] no marked change of the growth curves occurs when the conditions approach the precipitation lines or cross them (figure 2). In the case of CdS a clear change in the slope was observed and related to a change in the growth mechanism, from an atom by atom growth below the 
precipitation line to a colloidal growth beyond it. In the latter case the growth curve is linear with no induction time.

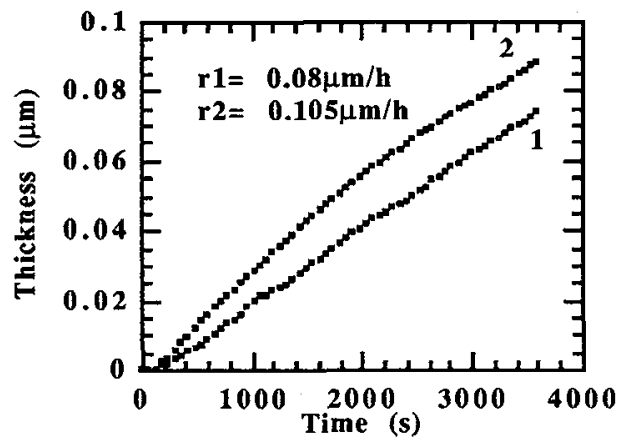

Figure 4: Thickness evolution with deposition time for sample prepared at different concentrations of thiourea. Conditions: $\left[\mathrm{NH}_{3}\right]=1.1 \mathrm{M}$,

$\left[\mathrm{ZnCl}_{2}\right]=0.15 \mathrm{M},\left[\mathrm{NH}_{4} \mathrm{Cl}\right]=0.02 \mathrm{M}$, $T=85^{\circ} \mathrm{C}, 1$ to $2[\mathrm{Tu}]=0.1,0.15 \mathrm{M}$.

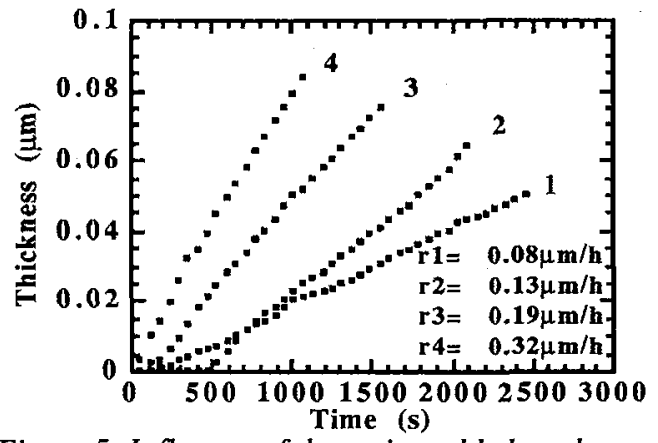

Figure 5: Influence of the amine added on the growth curves. Conditions: $\left[\mathrm{NH}_{3}\right]=1.1 \mathrm{M}$, $\left[\mathrm{ZnCl}_{2}\right]=0.15 \mathrm{M},\left[\mathrm{NH}_{4} \mathrm{Cl}\right]=0.02 \mathrm{M}$, $\mathrm{T}=85^{\circ} \mathrm{C}$; Curves 1 to $4: \mathrm{NH}_{3}$ only, $[T E A]=0.2 M,[E A]=0.7 M$, $[H Z]=3 M$.

This indicates that the growth mechanism more likely corresponds to a colloidal growth in these conditions. In [2] a strong effect of the addition of hydrazine on the growth rate of $\mathrm{ZnS}$ was observed, increasing the growth rate through a maximum situated at about $3 \mathrm{M}$. In figure 5 is shown the effect of addition of $3 \mathrm{M}$ hydrazine. An increase of the rate by a factor of 4 is also observed despite the complexing action (Table 1).The addition of triethanolamine also increases the growth rate markedly and the required concentrations are much lower $(0.2 \mathrm{M})$. In that case the complexing action is very low. One can note the appearance of an induction time in this case.

For ethanolamine $(0.7 \mathrm{M})$ an increase of the rate is also observed. In that case the complexing effect is much stronger than for the other species (Table $\mathrm{I}$ ). Considering the $\alpha$ coefficient shows that the free $\mathrm{Zn}^{2+}$ concentration is about ten time lower $\left(\alpha \approx 6.210^{7}\right.$ for $\mathrm{NH}_{3}, \mathrm{NH}_{3}+\mathrm{HZ}, \mathrm{NH}_{3}+\mathrm{TA}$ and $\alpha \approx 610^{8}$ for $\mathrm{NH}_{3}$ + EA), which should have lead to a significant decrease of the growth rate. This means that EA has a strong accelerating effect in the deposition mechanism. An effect of $\mathrm{pH}$ change can be avoided, since the added species have no acido basic properties in this $\mathrm{pH}$ range.

These results show that the addition of other amines tend to increase the growth rate, without changing significantly the speciation in the bath (precipitation line, $\mathrm{pH} .$. ) for $\mathrm{HZ}$ and TEA. This indicates a participation of these molecules in the reaction mechanism. In the case of hydrazine it is known that its presence accelerates the hydrolysis of thiourea (steps 2 and ii) and thus an increase of the rate is expected.

\subsection{Characterization of the films}

The films are adherent and homogeneous with thickness as around $0.1 \mu \mathrm{m}$.

Electron diffraction patterns for films deposited on carbon grid show a ring pattern, with large rings, corresponding to $\mathrm{ZnS}$ (c.f.c.) in a microcrystalline state. Electron transmission microscopy show that the films are composed of aggregated grains in a amorphous matrix (figure 6). The grain size is about $3 \mathrm{~nm}$. The interreticular distance $(0.372 \mathrm{~nm})$ corresponds to (111) planes. This indicates that the film is made by the aggregation of colloids from the solution, in agreement with the conclusions of the in situ study.

The composition of the films have been determined for films deposited on silicon substrates by means of Rutherford Back Scattering (RBS). The films appear to contain significant amounts of oxygen. In figure 7a is shown for instance the sprectra for a film deposited in the conditions of figure 4, curve 2 . The determination of the surface concentrations of $\mathrm{Zn}$ and $\mathrm{S}$ atoms gives a ratio about $2\left(22610^{15} \mathrm{~cm}^{-2}\right.$ for $\mathrm{Zn}$ and $11710^{15}$ for $S$ ). As the presence of oxygen is also detected, this means that the film is not pure sulfide but contains significant amount of oxyde $\left(\mathrm{ZnO}_{0.5} \mathrm{~S}_{0.5}\right)$ or hydroxide $\left(\mathrm{ZnOHS}_{0.5}\right)$. 


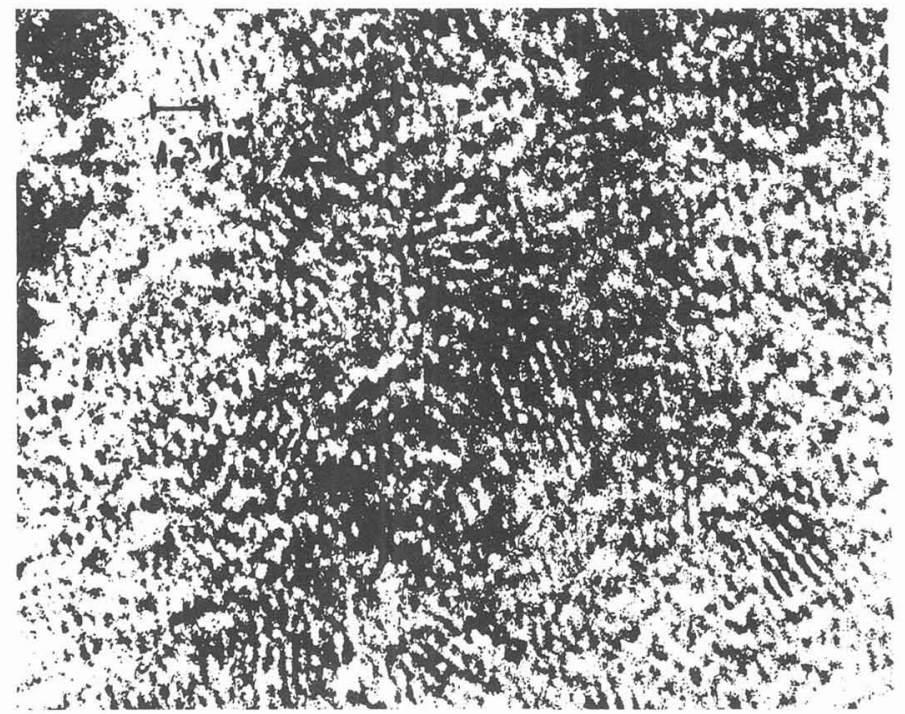

Figure 6: Electron transmission view of a film deposited on a carbon grid

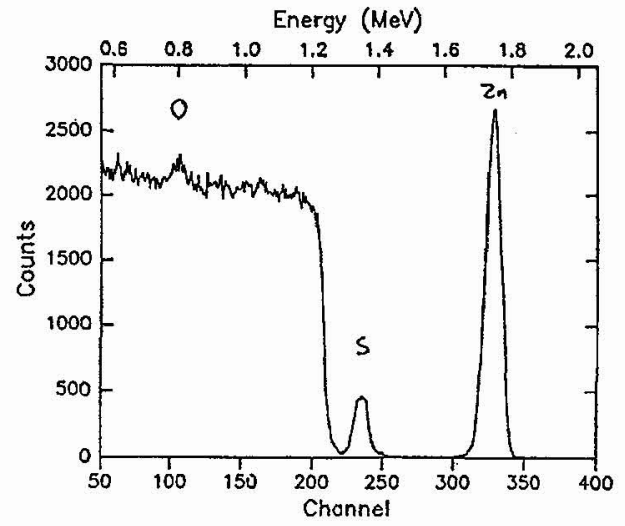

(a)

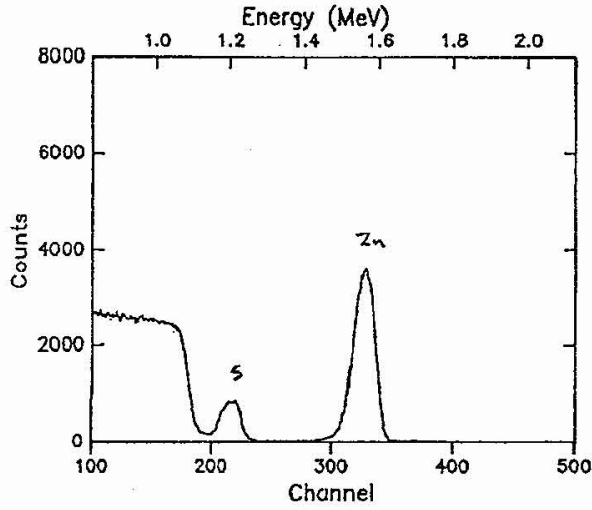

(b)

Figure 7: RBS spectra for films deposited on silicon. (a) $\left[\mathrm{NH}_{3}\right]=1.1 \mathrm{M},\left[\mathrm{ZnCl}_{2}\right]=0.15 \mathrm{M}$, $\left[\mathrm{NH}_{4} \mathrm{Cl}\right]=0.02 \mathrm{M},[\mathrm{Tu}]=0.15 \mathrm{M}, \mathrm{T}=85^{\circ} \mathrm{C}$ and $(\mathrm{b})\left[\mathrm{NH}_{3}\right]=1.2 \mathrm{M},\left[\mathrm{ZnSO}_{4}\right]=0.025 \mathrm{M}$, $[\mathrm{Tu}]=0.035 \mathrm{MT}=75^{\circ} \mathrm{C}$

EXAFS studies confirm the presence of oxygen in the form of hydroxide and the high $\mathrm{O} / \mathrm{S}$ ratio obtained in the films. The composition of some films is even close to $\mathrm{Zn}(\mathrm{OH})_{2}$ [18]. For comparison the RBS spectrum of a film close to stoichiometry is shown in figure $7 \mathrm{~b}$. It is obtained in more basic solutions, in presence of hydrazine in conditions similar to [2].

These results are coherent with the deposition mechanism involving hydroxide intermediates and the thermodynamic predictions of figure 1. If the transformation of hydroxide into sulfide is too slow, significant amounts of hydroxide will be present in the film. Otherwise in conditions of fast sulfide formation (with $\mathrm{HZ}$ in more basic conditions), the substitution of hydroxyl groups by sulfides is almost complete.

Optical transmission experiments are presented in figure 8. They show that the films are highly transparent with a well defined absorption edge in the UV range corresponding to band gap values of about $3.85 \mathrm{eV}$, slightly higher than for crystalline $\mathrm{ZnS}(\approx 3.6 \mathrm{eV})$. 


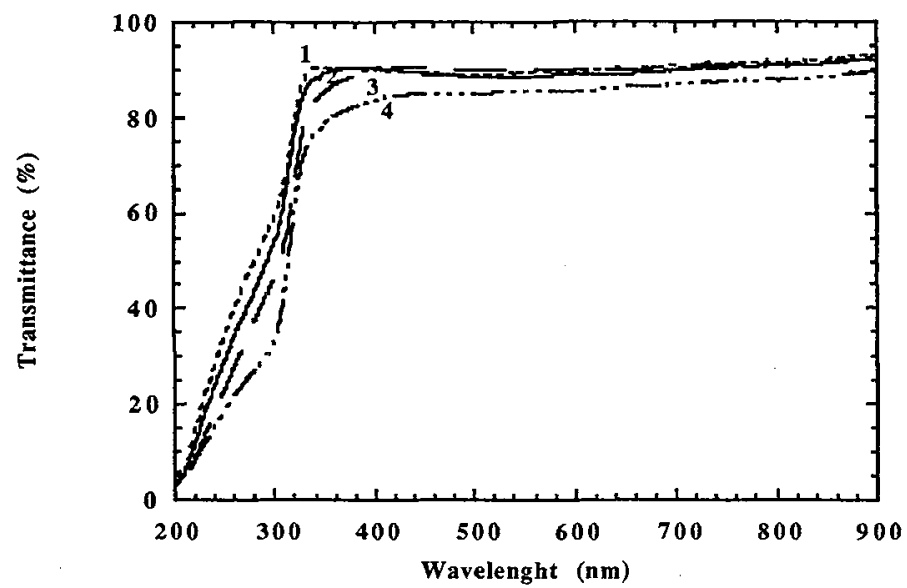

Figure 8: Optical transmission spectra; Curves 1 to 4: $\mathrm{NH}_{3}+\mathrm{EA}, \mathrm{NH}_{3}, \mathrm{NH}_{3}+\mathrm{TEA}, \mathrm{NH}+\mathrm{HZ}$, deposition conditions of figure 5.

\section{CONCLUSIONS}

The deposition of $\mathrm{ZnS}$ films in $\mathrm{pH}$ buffered ammonia solutions in presence or not of amines has been investigated.The solution chemistry analysis of the system allows to predict the conditions of $\mathrm{pH}$, concentrations of ammonia and zinc where $\mathrm{Zn}(\mathrm{OH})_{2}$ or $\mathrm{ZnS}$ precipitate. Films were deposited from these defined conditions.

The presence of an important quantity of oxide or hydroxide in the $\mathrm{ZnS}$ films can be explain by the proximity of solubility lines of the sulfide and the hydroxide. The conditions of precipitation correspond to the upper part of the plane. The sulfide is just a little more stable than the hydroxide.

The introduction of different amines (hydrazine, triethanolamine and ethanolamine) in the solution is found to enhance the growth rate. The films are adherent and highly transparent, with a band gap about $3.8 \mathrm{eV}$. They are microcrystalline and their composition varies from $\mathrm{ZnS}$ to $\mathrm{Zn}(\mathrm{OH})_{2}$.

\section{Acknowledgment}

This work is supported by the Commission of the European Communities in the frame of the EUROCIS programm (JOUR-0045-C), EUROCAD2 -CT92-0243 and the Agence de l'environnement et de la Maîtrise de l'Energie (ADEME-PIRSEM).

The authors are grateful to Dr. Jacques VEDEL for fruitful discussion.

\section{REFERENCES}

[1] Ortega Borges R., Lincot D. and Vedel J. in Proceeding. 11TH E.C. Photovotaic Solar Energy Conference, Montreux 12-16 october 1992, pp 862-865.

[2] Doña J.M. and Herrero J., J. Electrochem. Soc., 141(1) (1994) 205.

[3] Padam G.K., Malhotra G.L., Rao S.U.M., J. Appl. Phys., 63(3) (1988) 770.

[4] Nair P.K., Nair M.T.S. and Gomezadaza O., J. Electrochem. Soc., 140(4) (1993) 2915.

[5] Klein D.H. and Swift E.H., Talanta, 12 (1965) 363.

[6] Williams R., Yocom P.N.and Stofco F.S., J. of Colloid and Int. Sc., 106 (1985) 388.

[7] D. Lincot, R. Ortega-Borges and M. Froment, Appl. Phys. Lett., 64 (1994) 569.

[8] Ortega Borges R. and Lincot D., J. Electrochem. Soc., 140(12) (1993) 3464.

[9] K.L. Chopra, R.C. Kainthla, D.K. Pandya, and A.P. Thakoor, Phys. Thin Films, 12 (1982) 167.

[10] Kiteav G.A and Zhukhovskaya A.S., Russia J. Phys. Chem., 49(2) (1975) 275.

[11] Shaw W.H.R. and Walker D.G., J. Amer. Chem. Soc., 78 (1956) 5769.

[12] Kitaev G.A., Uritskaya A.A. and Mokrushin S.G., Russia J. Phys. Chem., 39(8) (1965) 1101.

[13] Kaur I., Pandya D.K, and Chopra K.L., J. Electrochem. Soc., 127(4) (1980) 943.

[14] Ringbom A., Les complexes en chimie analytique, (Dunod, Paris, 1967) pp 271-338.

[15] Kitaev G.A. Bol'shchiova A.S. and Yatlova L.E., Russ. J. Inorg. Chem., 16 (1971) 1683.

[16] Smith R.M. and Martell A.E., Critical stability constants, vol 2 (Plenum Press, New York 1975) p 15.

[17] Charlot G., L'analyse qualitative et les réactions en solution, (Masson \& Cie, Paris 1963) p380.

[18] Y. Charreire, unpublished results. 